\title{
Cotinine Exposure Increases Fallopian Tube PROKR1 Expression via Nicotinic $\mathrm{AChR} \alpha-7$
}

\section{A Potential Mechanism Explaining the Link between Smoking and Tubal Ectopic Pregnancy}

\author{
Julie L.V. Shaw, ${ }^{*}$ Elizabeth Oliver, ${ }^{*}$ Kai-Fai Lee, ${ }^{\dagger}$ \\ Gary Entrican, ${ }^{\ddagger}$ Henry N. Jabbour, ${ }^{*}$ \\ Hilary O.D. Critchley, ${ }^{*}$ and Andrew W. Horne* \\ From the Centre for Reproductive Biology, ${ }^{*}$ University of Edinburgh, \\ Queen's Medical Research Institute, Edinburgh, United Kingdom; \\ the Department of Obstetrics and Gynaecology, ${ }^{\dagger}$ The University of \\ Hong Kong, Pokfulam, Hong Kong, China; the Moredun Research \\ Institute, Edinburgh and the Roslin Institute, Royal (Dick) School of \\ Veterinary Studies, University of Edinburgh, Roslin Biocentre, \\ Midlothian, United Kingdom
}

Tubal ectopic pregnancy (EP) is the most common cause of maternal mortality in the first trimester of pregnancy; however, its etiology is uncertain. In EP, embryo retention within the Fallopian tube (FT) is thought to be due to impaired smooth muscle contractility (SMC) and alterations in the tubal microenvironment. Smoking is a major risk factor for EP. FTs from women with EP exhibit altered prokineticin receptor-1 (PROKR1) expression, the receptor for prokineticins (PROK). PROK1 is angiogenic, regulates SMC, and is involved in intrauterine implantation. We hypothesized that smoking predisposes women to EP by altering tubal PROKR1 expression. Sera/FT were collected at hysterectomy $(n=21)$. Serum levels of the smoking metabolite, cotinine, were measured by enzyme-linked immunosorbent assay. FTs were analyzed by q-RT-PCR, immunohistochemistry, and Western blotting for expression of PROKR1 and the predicted cotinine receptor, nicotinic acetylcholine receptor $\alpha-7(\operatorname{AChR} \alpha-7)$. FT explants $(n=4)$ and oviductal epithelial cells (cell line OE-E6/E7) were treated with cotinine and an $\mathrm{nAChR} \alpha-7$ antagonist. PROKR1 transcription was higher in FTs from smokers $(P<$ 0.01). nAChR $\alpha-7$ expression was demonstrated in FT epithelium. Cotinine treatment of FT explants and OE-E6/E7 cells increased PROKR1 expression $(P<0.05)$, which was negated by cotreatment with
nAChR $\alpha-7$ antagonist. Smoking targets human FTs via nAChR $\alpha-7$ to increase tubal PROKR1, leading to alterations in the tubal microenvironment that could predispose to EP. (Am J Pathol 2010, 177:2509-2515; DOI: 10.2353/ajpath.2010.100243)

Tubal ectopic pregnancy occurs in 1 to $2 \%$ of all pregnancies in Europe and the United States. ${ }^{1}$ In the Western world, it remains the most common cause of maternal mortality in the first trimester of pregnancy., ${ }^{1,2}$

Our current understanding of the underlying causes of tubal ectopic is based predominantly on descriptive observations rather than interventive experimentation. ${ }^{3} \mathrm{Nev}-$ ertheless, these observations support the hypothesis that tubal implantation is likely caused by embryo retention within the Fallopian tube due to impaired smooth muscle contractility and alterations in the tubal environment allowing implantation to occur. Transport of the embryo through the Fallopian tube is controlled by a combination of smooth muscle contractility and ciliary beating. ${ }^{4,5}$ The factors that regulate and maintain the normal tubal homeostatic environment are unknown.

Epidemiological studies have shown that cigarette smoking is a risk factor for tubal ectopic pregnancy. ${ }^{1,2,6}$ Animal and human studies have demonstrated effects on oviductal function resulting from smoke exposure. Inhalation of smoke has been reported to affect the electrical activity of the rabbit oviduct, ${ }^{7}$ to reduce the ratio of ciliated to secretory epithelial cells in the hamster oviduct, ${ }^{8}$

Supported by a Wellbeing of Women Project grant (RG993 to A.W.H.). H.N.J. was supported by Medical Research Council (MRC) Core Funding (U.1276.00.004.00002.02). G.E. was funded by the Scottish Government Rural and Environment Research and Analysis Directorate (RERAD). A.W.H. is supported by an MRC Clinician Scientist Fellowship.

Accepted for publication July 16, 2010

Address reprint requests to Dr. Andrew W. Horne, Centre for Reproductive Biology, Queen's Medical Research Institute, 47 Little France Crescent, Edinburgh, UK, EH16 4TJ. E-mail: andrew.horne@ed.ac.uk. 
and to temporarily influence patency of human Fallopian tube. ${ }^{9}$ Despite these findings, the exact mechanism by which smoking leads to tubal ectopic pregnancy remains unknown.

We recently reported down-regulated transcription of two G-protein-coupled receptors, prokineticin receptor 1 (PROKR1) and PROKR2, in Fallopian tube from women with tubal ectopic pregnancy, where implantation had already occurred. ${ }^{10}$ Ligands for these receptors, the prokineticins (PROK) 1 and PROK2, are proangiogenic. Placental PROK expression has been shown to be up-regulated in hypoxic conditions and, in the endometrium, PROK1 is reported to increase the expression of proangiogenic cytokines. ${ }^{11,12}$ PROKs are also known for regulating genes that are important in implantation. ${ }^{13}$ PROK1 has been shown to induce expression of leukemia inhibitory factor (LIF) in the human endometrium, and LIF is known to play a crucial role in successful intrauterine implantation in mice. ${ }^{14,15}$ Furthermore, PROKs have been shown to play a role in controlling smooth muscle contractility in rodent gut, and are thought to similarly control the tubal smooth muscle contractility which facilitates embryo-tubal transport. ${ }^{10,16}$ We hypothesized that cigarette smoking attenuates tubal PROKR expression resulting in changes in Fallopian tube function, providing a possible explanation for the link between smoking and tubal ectopic pregnancy.

Directly addressing this hypothesis in human subjects is not straightforward, and interpretation of studies on the physiological effects of smoke exposure can be difficult due to technical constraints. Nicotine is the major constituent of tobacco smoke but is difficult to measure or study because of its very short half-life. ${ }^{17}$ Cotinine, the most abundant metabolite of nicotine, has been identified as a stable biomarker of smoke exposure and has been used in cell culture to mimic the affects of smoke exposure in vitro, reportedly signaling though the nicotinic acetylcholine receptor $\alpha-7$ (nAChR $\alpha-7) .{ }^{17-19}$ Thus, to objectively address our hypothesis, we compared serum cotinine levels to PROKR expression in human Fallopian tube. We also examined the effects of cotinine on tubal PROKR expression in Fallopian tube in vitro and investigated whether this was mediated via $\mathrm{nAChR} \alpha-7$.

\section{Materials and Methods}

\section{Human Tissue Collection}

Ethical approval for this study was obtained from the Lothian Research Ethics Committee (04/S1103/20), and informed consent was obtained from all of the women participating in the study. Serum samples $(10 \mathrm{ml})$ and Fallopian tube biopsies $(2-3 \mathrm{~cm}$ ) from the ampullary region of the Fallopian tube were all collected from participants at the time of hysterectomy $(n=25)$. Women were between 18 and 45 years of age. The clinical details for each participant are listed in Table 1. A smoking history was obtained from all patients. None of the patients included in the study were known to have been exposed to chlamydial infection. The biopsies were divided into three portions and were either i) stored in phosphate-buffered saline (PBS) before explant culture, ii) immersed in RNAlater (Ambion, Texas, USA) at

Table 1. Clinical Details for Patient Samples

\begin{tabular}{|c|c|c|c|c|c|}
\hline Sample no. & $\begin{array}{c}\text { Age } \\
\text { (years) }\end{array}$ & $\begin{array}{l}\text { Serum estrogen } \\
(\mathrm{pmol} / \mathrm{L})\end{array}$ & $\begin{array}{c}\text { Serum progesterone } \\
(\mathrm{nmol} / \mathrm{L})\end{array}$ & $\begin{array}{l}\text { Reason for } \\
\text { surgery }\end{array}$ & $\begin{array}{l}\text { Uterine } \\
\text { pathology }\end{array}$ \\
\hline 1 & 37 & 392.18 & 3.06 & $\mathrm{HMB}$ & No abnormality \\
\hline 2 & 41 & 1022.87 & 0.81 & $\mathrm{HMB}$ & Adenomyosis \\
\hline 3 & 37 & 940.44 & 3.82 & $\mathrm{HMB}, \mathrm{PP}$ & Adenomyosis \\
\hline 4 & 44 & 829.42 & 4.19 & $\mathrm{HMB}, \mathrm{PP}$ & Adeomyosis \\
\hline 5 & 36 & 770.63 & 5.16 & $\mathrm{HMB}$ & No abnormality \\
\hline 6 & 44 & 116.3 & 2.88 & $\mathrm{HMB}, \mathrm{PP}$ & No abnormality \\
\hline 7 & 45 & 55.0 & 2.2 & $\mathrm{HMB}, \mathrm{PP}$ & Adenomyosis \\
\hline 8 & 32 & 549.91 & 88 & Dysmen & No abnormality \\
\hline 9 & 40 & 242 & 53.1 & $\mathrm{HMB}$, dysmen & No abnormality \\
\hline 10 & 43 & 201 & 24.55 & $\mathrm{HMB}, \mathrm{PP}$ & Fibroid \\
\hline 11 & 43 & 399.8 & 80.45 & HMB, dysmen & Adenomyosis \\
\hline 12 & 40 & 1633.0 & 54.38 & $\mathrm{HMB}$, dysmen & No abnormality \\
\hline 13 & 38 & 4.39 & 83 & $\mathrm{HMB}$, dysmen & No abnormality \\
\hline 14 & 35 & 424 & 76.9 & $\mathrm{PP}$ & No abnormality \\
\hline 15 & 40 & 155.5 & 7.41 & HMP, dysmen & No abnormality \\
\hline 16 & 38 & 266 & 37.1 & $\mathrm{HMB}$ & No abnormality \\
\hline 17 & 43 & 242.9 & 38.1 & $\mathrm{HMB}$ & No abnormality \\
\hline 18 & 40 & 255 & 49.05 & HMB & No abnormality \\
\hline 19 & 35 & 73 & 2.67 & HMB, dysmen & Adenomyosis \\
\hline 20 & 37 & 392.18 & 3.06 & Dysmen & No abnormality \\
\hline 21 & 42 & 55 & 15.05 & $\mathrm{HMB}$ & No abnormality \\
\hline \multicolumn{6}{|c|}{ Used in explant studies } \\
\hline 22 & 38 & 38.2 & 7.09 & $\mathrm{HMB}$ & No abnormality \\
\hline 23 & 43 & 338.4 & 29.19 & $\mathrm{HMB}$ & Fibroid \\
\hline 24 & 46 & 282.2 & 22.29 & $\mathrm{HMB}$ & No abnormality \\
\hline 25 & 47 & 87.7 & 4.48 & Dysmen & No abnormality \\
\hline
\end{tabular}


$4^{\circ} \mathrm{C}$ overnight and then flash frozen at $-80^{\circ} \mathrm{C}$ for RNA extraction, or iii) fixed in $4 \%$ neutral-buffered formalin overnight at $4^{\circ} \mathrm{C}$ followed by storage in $70 \%$ ethanol, and subsequent embedding in paraffin wax for immunohistochemical staining. Serum samples were stored at $-20^{\circ} \mathrm{C}$ until analysis.

\section{ELISA for Serum Cotinine Levels}

Serum cotinine levels were measured using the direct cotinine ELISA kit (Immunalysis, Pomona, CA), according to the manufacturer's instructions. ELISA data were analyzed in conjunction with the smoking history provided by the participants.

\section{Quantitative RT-PCR for PROKR in Fallopian Tube and the OE-E6/E7 Cell Line}

RNA (200 ng) was reverse transcribed into cDNA in a $10-\mu$ l reaction using random hexamers (Applied Biosystems, Foster City, CA). Taqman RT-PCR was used to quantify PROK and PROKR mRNA transcript. Reactions were performed using an ABI Prism 7900 (Applied Biosystems) using standard conditions. All primers and probes were previously validated, ${ }^{20}$ and the sequences are listed in Table 2. All reactions were performed in triplicate. Gene expression was normalized to RNA loading using primers and VIC-labeled probe (Applied Biosystems) for ribosomal $18 \mathrm{~S}$ as an internal standard and expressed as relative to a positive RNA standard (cDNA from a single mid-secretory endometrial tissue) which was included in all reactions.

\section{Immunohistochemistry of Fallopian Tube for $n A C h R \alpha-7$}

Immunohistochemistry was performed using standard techniques as previously described. ${ }^{10} \mathrm{AChR} \alpha-7 \mathrm{rab}-$ bit anti-human polyclonal antibody (Santa Cruz Biotechnology, Santa Cruz, CA) was diluted 50-fold in

Table 2. $\quad$ RRT-PCR Primer and Probe Sequences

\begin{tabular}{|c|c|}
\hline $\begin{array}{l}\text { Primer/probe } \\
\text { (label) }\end{array}$ & Sequence \\
\hline $\begin{array}{l}\text { PROK1 forward } \\
\text { PROK1 reverse } \\
\text { PROK1 probe } \\
\text { (FAM) } \\
\text { PROKR1 forward } \\
\text { PROKR1 reverse } \\
\text { PROKR1 probe } \\
\text { (FAM) } \\
\text { PROK2 forward } \\
\text { PROK2 reverse } \\
\text { PROK2 probe } \\
\text { (FAM) } \\
\text { PROKR2 forward } \\
\text { PROKR2 reverse } \\
\text { PROKR2 probe } \\
\text { (FAM) } \\
\text { 18S forward } \\
\text { 18S reverse } \\
\text { 18S probe }(\mathrm{VIC})\end{array}$ & $\begin{array}{l}\text { 5'-GTGCCACCCCGGCAG-3' } \\
\text { 5'-AGCAAGGACAGGTGTGGTGC-3' } \\
\text { 5'-ACAAGGTCCCTTCTTCAGGAAACGCA-3' } \\
\text { 5'-TCTTACAATGGCGGTAAGTCCA-3' } \\
\text { 5'-CTCTTCGGTGGCAGGCAT-3' } \\
\text { 5'-TGCAGACCTGGACCTCAAGACAATTGG-3' } \\
\text { 5'-TTGGGCGGAGGATGCA-3' } \\
\text { 5'-AAATGAAGTCCGTAAACAGGCC-3' } \\
\text { 5'-CACTTGCCCATGTCTGCCAGGCT-3' } \\
\text { 5'-GCTCTGTGCCTCCGTCAACT-3' } \\
\text { 5'-CCAGCAAGGCATTGGTGG-3' } \\
\text { 5'-CCTGCGCACCGTCTCCCTCTACG-3' } \\
\\
\text { 5'-CGGCTACCACATCCAAGGAA-3' } \\
\text { 5'-GCTGGAATTACCGCGGCT-3' } \\
\text { 5'-TGCTGGCACCAGACTTGCCCTC-3' }\end{array}$ \\
\hline
\end{tabular}

normal goat serum. Rabbit IgG, diluted to the same concentration as the $\mathrm{nAChR} \alpha-7$ antibody, was used as a negative control.

\section{SDS-PAGE and Western Blotting for PROKR and $n A C h R \alpha-7$ in Fallopian Tube and the OE-E6/E7 Cell Line}

Twenty micrograms of whole cell lysate was resolved by SDS-PAGE, after which proteins were transferred to nitrocellulose. A lysate from Ishikawa cells stably expressing PROKR1 was used as a positive control for PROKR1 (data not shown). Membranes were blocked overnight at $4^{\circ} \mathrm{C}$ in $5 \%$ milk in Tris-buffered saline-tween (TBST). Membranes were blotted with antibodies diluted in $1 \%$ milk in TBST; rabbit anti-human PROKR1, 2500-fold (MBL International Corporation, Woburn, MA) or rabbit antihuman AChR $\alpha-7$ polyclonal, 200-fold (Santa Cruz Biotechnology, Santa Cruz, CA). These incubations were performed for one hour at room temperature following which the membranes were washed three times in TBST. The membranes were then incubated with mouse antirabbit-IgG conjugated to HRP diluted 20,000-fold in 1\% milk in TBST for one hour at room temperature. Membranes were washed as above, and proteins were detected using chemiluminescent HRP substrate (Millipore, Watford, UK) and exposed to film (GE Health care, Little Chalfont, UK). Membranes were stripped of PROKR1 antibody and reprobed, as above, with rabbit antihuman $\beta$-actin antibody (Abcam, Cambridge, UK), diluted 15,000 -fold in $1 \%$ milk in TBST as a loading control. Densitometry analysis was performed using ImageJ software (NIH, Bethesda, MD), and the density of PROKR1 was normalized to the density of $\beta$-actin in each well.

\section{Treatment of Human Fallopian Tube Explants with Cotinine}

Fallopian tube explant culture was performed using four Fallopian tubes from four individual patients as previously described..$^{10}$ Explants were treated with $40 \mathrm{ng} / \mathrm{ml}$ cotinine (Sigma-Aldrich, Dorset, UK), which represents cotinine concentrations found in the serum of passive smokers, ${ }^{21}$ and $400 \mathrm{ng} / \mathrm{ml}$, the average concentration found in the serum of active smokers in our study (Table 1). Explants were also treated with equivalent amounts of ethanol as a control for the cotinine diluent. Preliminary time-course studies were performed to determine the optimal treatment time for measuring changes in PROKR1 mRNA expression. Based on those results, treatments were performed on duplicate explants for 8 hours, at which time the culture medium was removed and tissues placed in $300 \mu \mathrm{l}$ of Trizol reagent (Invitrogen, Paisley, UK) and frozen at $-80^{\circ} \mathrm{C}$ until RNA extraction. RNA was extracted using Trizol (Invitrogen) according to the manufacturer's instructions. After RNA extraction, DNAase treatment was performed followed by sample clean-up using the RNAeasy kit (Qiagen, West Sussex, 
UK). RNA concentrations were then quantified using a Nanodrop Spectrophotometer (Thermo Scientific, Wilmington, DE).

\section{Treatment of OE-E6/E7 Cell Line with Cotinine and the $n A C h R \alpha-7$ Receptor Antagonist}

OE-E6/E7 cells ${ }^{22}$ were maintained in DMEM/F12 medium supplemented with $10 \%$ fetal bovine serum (growth medium) in $5 \% \mathrm{CO}_{2}$ at $37^{\circ} \mathrm{C}$. Cells were seeded at 500,000 cells per well in 12-well dishes and incubated for 24 hours. The growth medium was then removed and cells washed once with PBS, after which serum-free DMEM/ F12 (maintenance medium) was added and the cells maintained overnight. The medium was then removed and cells were either pretreated with $2 \mu \mathrm{g} / \mathrm{ml} \alpha$-bungarotoxin, a $\mathrm{nAChR} \alpha-7$ antagonist (Biotium, Hayward CA, USA) in maintenance medium for 30 minutes $^{19}$ after which $400 \mathrm{ng} / \mathrm{ml}$ cotinine (Sigma-Aldrich, Dorset, UK) in maintenance medium was added or cells were treated with $400 \mathrm{ng} / \mathrm{ml}$ cotinine alone. In all cases cells were also treated with an equivalent amount of ethanol to control for the cotinine diluent. Cells were treated for 8 hours, and medium was then removed and cells harvested into 300 $\mu$ l of RLT buffer (Qiagen, West Sussex, UK) containing 10 $\mu \mathrm{l} / \mathrm{ml} \beta$-mercaptoethanol and stored at $-80^{\circ} \mathrm{C}$ until RNA extraction. RNA was extracted using the RNA easy kit (Qiagen, West Sussex, UK), according to the manufacturer's instructions which included a DNase treatment step. After extraction, RNA concentrations were quantified as above. For protein analysis, treatments were performed for 9 hours, the optimal time for detecting changes in PROKR1 protein expression, determined by preliminary time-course experiments. Cells were harvested in $250 \mu$ I RIPA buffer (1\% Triton X, 0.1\% SDS, 150 $\mathrm{mmol} / \mathrm{L} \mathrm{NaCl}, 20 \mathrm{mmol} / \mathrm{L}$ Tris, $\mathrm{pH}$ 7.4). Lysates were prepared by incubation of cells on ice for 15 minutes followed by centrifugation at 13,000 rpm for 15 minutes at $4^{\circ} \mathrm{C}$ to remove membranous material. Total protein concentrations of the lysates were determined by Bradford assay and measured using a Cobas Fara (Roche Diagnostics, Welwyn Garden City, UK) centrifugal analyzer.

\section{Statistical Analysis}

Statistical analyses were performed using GraphPad Prism (version 5.0, GraphPad Software, La Jolla, CA). Differences in PROKR levels in Fallopian tube from smokers versus nonsmokers were determined using the Man$\mathrm{n}-$ Whitney test. Where q-RT-PCR found undetermined transcript levels, samples were removed from the analysis. Comparisons of PROKR1 levels in treated tissues and OE-E6/E7 cells were performed using one-way analysis of variance (analysis of variance) followed by NewmanKeul's post hoc analysis.
Table 3. Cotinine Levels in Patient Sera and Self-Reported Smoking Status of Patients

\begin{tabular}{cclc}
\hline Sample \# & $\begin{array}{c}\text { Serum } \\
\text { cotinine } \\
(\mathrm{ng} / \mathrm{ml})\end{array}$ & $\begin{array}{c}\text { Self-reported } \\
\text { smoking status }\end{array}$ & $\begin{array}{c}\text { Number } \\
\text { of years } \\
\text { smoking }\end{array}$ \\
\hline 1 & $<5$ & Nonsmoker & \\
2 & 11.3 & Nonsmoker & \\
3 & $<5$ & Nonsmoker & \\
4 & 8.6 & Nonsmoker & \\
5 & 7.4 & Nonsmoker & \\
6 & $<5$ & Nonsmoker & \\
7 & $<5$ & Nonsmoker & \\
8 & $<5$ & Nonsmoker & \\
9 & $<5$ & Nonsmoker & \\
10 & $<5$ & Nonsmoker & $5-8$ \\
11 & 161 & Smoker & \\
12 & $<5$ & Nonsmoker & \\
13 & $<5$ & Nonsmoker & Unknown \\
14 & 355 & Smoker & \\
15 & $<5$ & Nonsmoker & $20-30$ \\
16 & $>500$ & Smoker & 20 \\
17 & $>500$ & Smoker & \\
18 & $<5$ & Nonsmoker & 20 \\
19 & $>500$ & Smoker & $10-15$ \\
20 & $<5$ & Nonsmoker & 10 \\
21 & $>500$ & Smoker & \\
22 & $>500$ & Smoker & \\
\hline
\end{tabular}

\section{Results}

\section{Relationship between Patient Serum Cotinine Concentrations and Self-Reported Smoking Status}

A very strong relationship was observed between serum cotinine concentrations and the self-reported smoking status of the patients in this study (Table 3). All smokers had serum cotinine concentrations in excess of $160 \mathrm{ng} / \mathrm{ml}$ while the concentration in the serum of nonsmokers did not exceed $12 \mathrm{ng} / \mathrm{ml}$, indicating that cotinine is a good biomarker for smoking. A previous report has found that nonsmokers have serum cotinine levels less than $40 \mathrm{ng} /$ $\mathrm{ml} .{ }^{23}$ The concentrations reported in our patients are in agreement with that study, and therefore samples were divided into two groups: i) nonsmokers (cotinine $<40$ $\mathrm{ng} / \mathrm{ml}$ ) and ii) smokers (cotinine $>40 \mathrm{ng} / \mathrm{ml}$ ).

\section{Relationship between PROK and PROKR mRNA Expression in Fallopian Tube Tissue and Serum Cotinine Levels}

No significant differences in the levels of mRNA encoding PROK1, PROK2, and PROKR2 in Fallopian tube were found between smokers and nonsmokers. However, the expression of mRNA encoding PROKR1 was found to be significantly higher (approximately twofold; $P<0.01$ ) in Fallopian tube from smokers compared to Fallopian tube from nonsmokers (Figure 1A). These data suggest an association between PROKR1 expression, serum cotinine expression, and cigarette smoking. To investigate this further, we treated Fallopian tube explants with $400 \mathrm{ng} / \mathrm{ml}$ cotinine, a concentration lower than that found in the 
A Human Fallopian tube exposed to cotinine in vivo
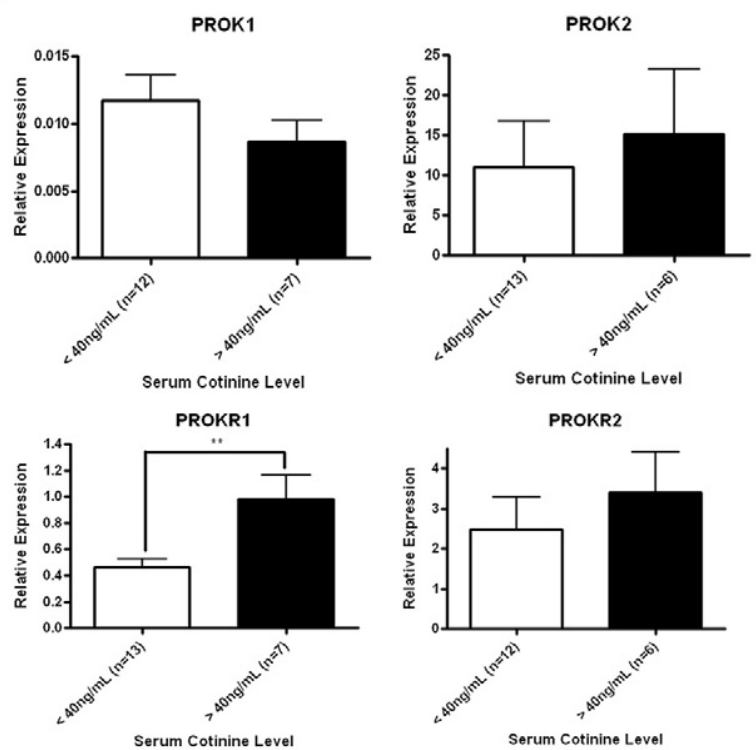

B Human Fallopian tube explants exposed to cotinine in vitro

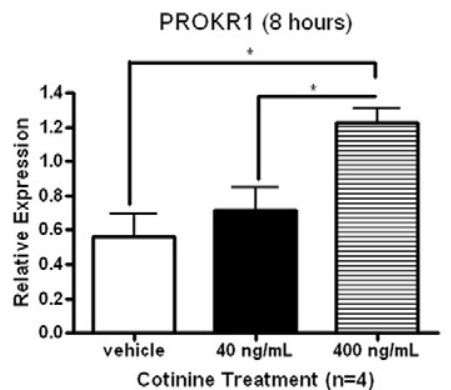

Figure 1. PROKR mRNA levels in Fallopian tubes from smokers and nonsmokers and in Fallopian tube explants treated with cotinine. A: The women were divided into two groups, nonsmokers and smokers, based on their serum cotinine levels and self-reported smoking status. PROK1, PROK2, PROKR1, and PROKR2 mRNA levels were measured by q-RT-PCR. B: Fallopian tube explants were cultured and treated for 8 hours with cotinine at levels reported to be representative of passive $(40 \mathrm{ng} / \mathrm{ml})$ and active $(400$ $\mathrm{ng} / \mathrm{ml}$ ) smokers, and PROKR1 mRNA levels were measured using q-RT-PCR. ${ }^{*} P<0.05,{ }^{* *} P<0.01$.

serum of all but one of the active smokers included in our study, and found that this induced a significant two- to threefold increase in PROKR1 mRNA expression (Figure 1B; $P<0.05)$. Past Chlamydia trachomatis infection was considered a potential confounder (another major risk factor for ectopic pregnancy). This was addressed by measuring serum levels of $\mathrm{PgP}$ antibodies (indicative of past Chlamydia infection) in patient serum by ELISA. There was no relationship between serum $\mathrm{PgP}$ and PROKR1 mRNA expression levels (data not shown).

\section{Expression of Nicotinic Acetylcholine Receptor $\alpha-7$ (nAChR $\alpha-7)$ by Fallopian Tube and OE-E6/E7 Cells}

The epithelium of the ampullary region of the human Fallopian tube was found to express $\mathrm{AChR} \alpha-7$ by immunohistochemistry using a specific rabbit polyclonal antibody (Figure 2A, main image) that was not observed
A

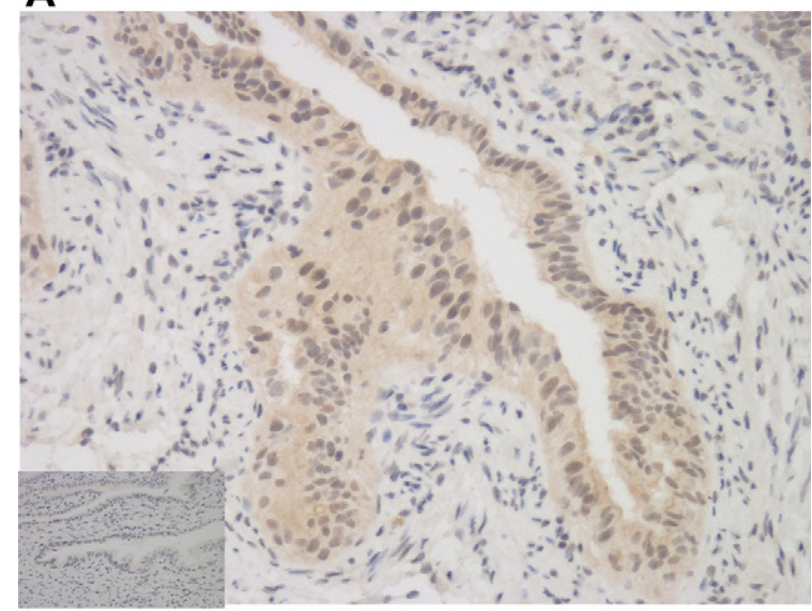

B

$\mathrm{kDa}$

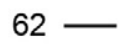

$55 \mathrm{KDa} \mathrm{nAChR} \alpha 7$

49

Figure 2. Expression of $\mathrm{nAChR} \alpha-7$ in Fallopian tubes and $\mathrm{OE}-\mathrm{E} 6 / \mathrm{E} 7$ cells A: Immunohistochemical staining of Fallopian tubes with rabbit polyclonal IgG antibody specific for $\mathrm{nAChR} \alpha-7$ (main image) and control rabbit IgG (inset) at $\times 100$ magnification. B: Lysates of OE-E6/E7 cells resolved by SDS-PAGE, transferred to nitrocellulose, and blotted with a rabbit IgG antibody specific for $n A C h R \alpha-7$.

using a control rabbit IgG (Figure 2A, inset). The same specific antibody was used to probe lysates of OE-E6/E7 cells by Western blotting and show that this cell line also expresses $\mathrm{nAChR} \alpha-7$, as indicated by a band at the predicted molecular weight of $55 \mathrm{kDa}$ (Figure 2B). Thus, both Fallopian tube explants and the OE-E6/E7 cell line have the potential to respond to cotinine via ligation of the $\mathrm{nAChR} \alpha-7$.

\section{Effect of the $n A C h R \alpha-7$ Receptor Antagonist $\alpha$-Bungarotoxin on Cotinine-Induced on PROKR1 Expression in OE-E6/E7 Cells}

Consistent with the previous observations in Fallopian tube, OE-E6/E7 cells were found to up-regulate PROKR1 $\mathrm{mRNA}$ levels in response to $400 \mathrm{ng} / \mathrm{ml}$ cotinine (Figure 3A; $P<0.05)$. This effect was found to be negated by pretreatment of cells with $\alpha$-bungarotoxin (Figure 3A). Western blot and densitometry analysis $(n=6)$ show that PROKR1 protein levels were also increased in OE-E6/E7 cells exposed to $400 \mathrm{ng} / \mathrm{ml}$ cotinine, an effect that was also negated by pretreatment with $\alpha$-bungarotoxin (Figure 3B). 
A

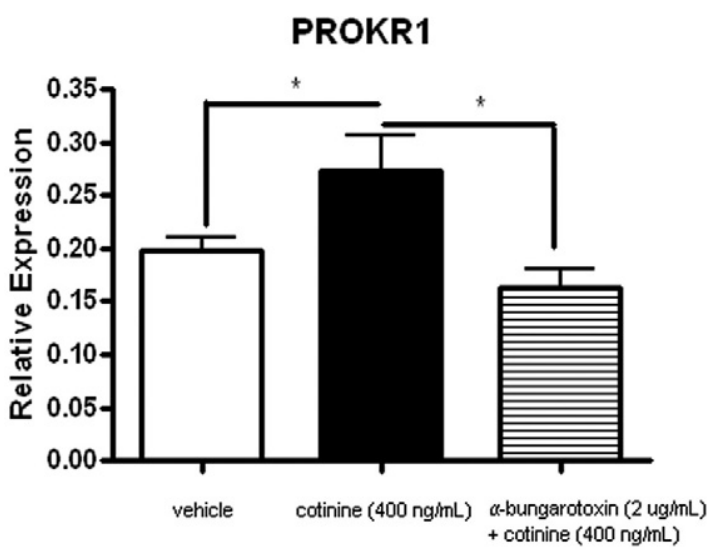

B

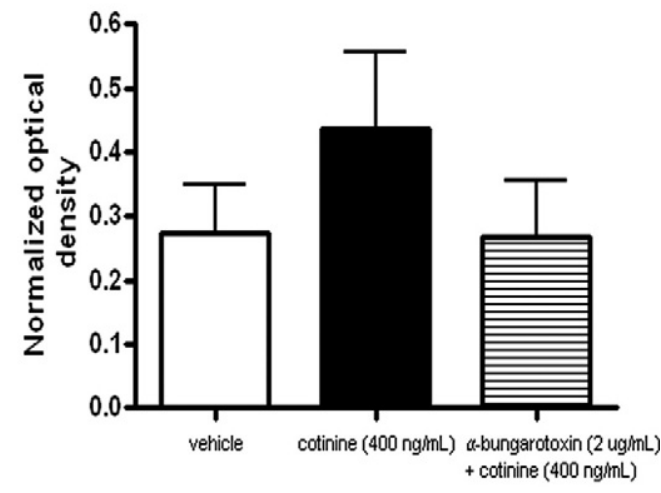

$39 \mathrm{kDa}$ PROKR1

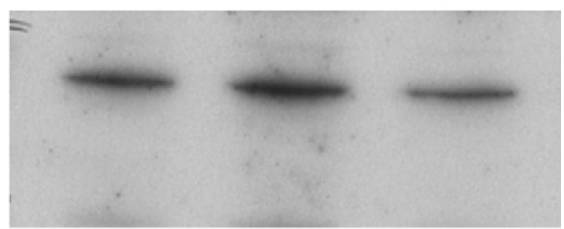

$42 \mathrm{kDa}$ B-actin

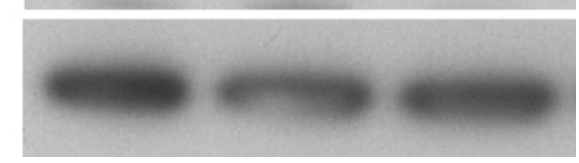

Figure 3. Effect of the $\mathrm{nAChR} \alpha-7, \alpha$-bungarotoxin, on cotinine-induced PROKR1 expression in OE-E6/E7 cells. OE-E6/E7 cells were treated with 400 $\mathrm{ng} / \mathrm{ml}$ cotinine or pretreated for 30 minutes with the nAChR $\alpha-7$ antagonist, $\alpha$-bungarotoxin, followed by $400 \mathrm{ng} / \mathrm{ml}$ cotinine. Cells were treated with cotinine for 8 hours for mRNA analysis (A) and for 9 hours for protein analysis $(\mathbf{B}) .{ }^{*} P<0.05$.

\section{Discussion}

This study provides evidence that altered Fallopian tube PROKR1 expression may explain the link between smoking and tubal ectopic pregnancy. Smoking is associated with other adverse effects on human reproduction, in addition to tubal ectopic pregnancy, such as infertility and spontaneous abortion, ${ }^{24}$ making this is an important finding in the broader context of reproductive health.

We recently reported that there are significantly lower levels of PROKR1 in nonpregnant Fallopian tube collected during the follicular phase compared to the midluteal phase (so called 'window of implantation') of the menstrual cycle. ${ }^{10,25}$ We also showed that Fallopian tube obtained from women with tubal ectopic pregnancy, where tubal implantation had occurred, had significantly lower levels of PROKR compared to nonpregnant Fallopian tube. ${ }^{10}$ The difficulty in studying implantation is that tissues are collected after an implantation event has occurred, making it hard to ascertain whether differences observed are the result of a predisposing factor or implantation itself. However, our previous findings, ${ }^{10}$ together with the purported roles of PROK1 in intrauterine implantation, ${ }^{13-15}$ led us to hypothesize that dysregulated PROKR1 expression might predispose the tubal environment to ectopic pregnancy.

Herein, we demonstrate that PROKR1 expression is increased in Fallopian tube from women who are smokers. We also show that PROK1 levels appear to be decreased in Fallopian tube from smokers compared to nonsmokers, however this difference was not statistically significant. It could be that a negative feedback mechanism exists between PROKR1 and PROK1. We report that a metabolite of cigarette smoke, cotinine, increases PROKR1 expression in cultured Fallopian tube explants and in the immortalized oviductal epithelial cell line, OE-E6/E7. Nicotine is known to signal through nicotinic acetylcholine receptors $(n A C h R)^{18}$ with cotinine reported to signal through a specific member of this family, $\mathrm{nAChR} \alpha-7 .^{19}$ We demonstrate that human Fallopian tube epithelium and the OE-E6/E7 cell line express $\mathrm{nAChR} \alpha-7$. We also establish that treatment of OE-E6/E7 cells with a specific and potent $\mathrm{nAChR} \alpha-7$ antagonist ( $\alpha$-bungarotoxin), before cotinine treatment, negates the increase in PROKR expression observed when cells are treated with cotinine alone.

It is possible that increased PROKR1 expression in the Fallopian tube, as a result of smoking, predisposes the tubal environment to implantation through dysregulation of factors important for embryo receptivity and angiogenesis. PROK1 has been demonstrated to regulate the expression of genes important for implantation, such as cyclooxygenase 2 (COX2), dickkhopf-1 (DKK1), and LIF, in the human endometrium. ${ }^{13}$ Furthermore, PROK1 was recently reported to enhance the adhesion of human trophoblast cells to extracellular matrix proteins. ${ }^{15}$ This effect was shown to be mediated through PROK1 upregulation of LIF, suggesting that increased PROK1 activity may result in enhanced endometrial receptivity. PROKs are potent angiogenic factors. ${ }^{26}$ Angiogenesis is an important feature of successful intrauterine implantation allowing the uterine vasculature to adapt to meet the nutritional needs of the growing fetus, ${ }^{27}$ further suggesting that increased PROK signaling may lead to a tubal microenvironment predisposed to implantation.

Interestingly, cigarette smoking is associated with a decreased risk of preeclampsia, and it is hypothesized that dysregulated PROK1 expression, and the development of a proangiogenic phenotype during early placentation, may be implicated in the development of this condition. ${ }^{28}$ Similar to our findings in the Fallopian tube, it is possible that the effects of cigarette smoke on the placenta are mediated through $\mathrm{nAChR} \alpha-7$ resulting in up-regulated PROKR1 expression and increased PROK1 activity. Thus, we conclude that the human Fallopian tube serves as a useful model to evaluate the effect of cigarette smoke, and its components, on a reproductive organ remote to the site of inhalation, and in a more general sense on a variety of biological functions. 


\section{Acknowledgments}

We thank Paula Lourenco and Sheila Wright for technical support; Catherine Cairns, Sharon McPherson, and Catherine Murray for recruitment of patients; and Ronnie Grant for graphical assistance.

\section{References}

1. Farquhar CM: Ectopic pregnancy. Lancet 2005, 366:583-591

2. Varma R, Gupta J: Tubal ectopic pregnancy. Clin Evid (Online) 2009, 4:1406

3. Shaw JL, Dey SK, Critchley HO, Horne AW: Current knowledge of the aetiology of human tubal ectopic pregnancy. Hum Reprod Update 2010, 16:432-444

4. Jansen RP: Endocrine response in the fallopian tube. Endocr Rev 1984, 5:525-55

5. Lindblom B, Hamberger L, Ljung B: Contractile patterns of isolated oviductal smooth muscle under different hormonal conditions. Fertil Steril 1980, 33: 283-287

6. Walker JJ: Ectopic pregnancy. Clin Obstet Gynecol 2007, 50:89-99

7. Ruckebusch Y: Relationship between the electrical activity of the oviduct and the uterus of the rabbit in vivo. J Reprod Fertil 1975 , 45:73-82

8. Magers T, Talbot P, DiCarlantonio G, Knoll M, Demers D, Tsai I, Hoodbhoy $\mathrm{T}$ : Cigarette smoke inhalation affects the reproductive system of female hamsters. Reprod Toxicol 1995, 9:513-525

9. Neri A, Eckerling B: Influence of smoking and adrenaline (epinephrine) on the uterotubal insufflation test (Rubin test). Fertil Steril 1969, 20:818-828

10. Shaw JL, Denison FC, Evans J, Durno K, Williams AR, Entrican G, Critchley $\mathrm{HO}$, Jabbour HN, Horne AW: Evidence of prokineticin dysregulation in Fallopian tube from women with ectopic pregnancy Fertil Steril 2010, doi: 10.1016/jfertnstert.2009.10.061

11. Maldonado-Perez D, Brown P, Morgan K, Millar RP, Thompson EA, Jabbour HN: Prokineticin 1 modulates IL-8 expression via the calcineurin/NFAT signaling pathway. Biochim Biophys Acta 2009, 1793:1315-1324

12. Hoffmann P, Feige JJ, Alfaidy N: Expression and oxygen regulation of endocrine gland-derived vascular endothelial growth factor/prokineticin-1 and its receptors in human placenta during early pregnancy. Endocrinology 2006, 147:1675-1684

13. Evans J, Catalano RD, Morgan K, Critchley HO, Millar RP, Jabbour $\mathrm{HN}$ : Prokineticin 1 signaling and gene regulation in early human pregnancy. Endocrinology 2008, 149:2877-2887
14. Fouladi-Nashta AA, Jones CJ, Nijjar N, Mohamet L, Smith A, Chambers I, Kimber SJ: Characterization of the uterine phenotype during the peri-implantation period for LIF-null. MF1 strain mice. Dev Biol 2005, 281:1-21

15. Evans J, Catalano RD, Brown P, Sherwin R, Critchley HO, Fazleabas AT, Jabbour HN: Prokineticin 1 mediates fetal-maternal dialogue regulating endometrial leukemia inhibitory factor. FASEB J 2009, 23:2165-2175

16. Li M, Bullock CM, Knauer DJ, Ehlert FJ, Zhou QY: Identification of two prokineticin cDNAs: recombinant proteins potently contract gastrointestinal smooth muscle. Mol Pharmacol 2001, 59:692-698

17. Benowitz NL: The use of biologic fluid samples in assessing tobacco smoke consumption. NIDA Res Monogr 1983, 48:6-26

18. Yildiz D: Nicotine, its metabolism and an overview of its biological effects. Toxicon 2004, 43:619-632

19. Rehani K, Scott DA, Renaud D, Hamza H, Williams LR, Wang $H$, Martin M: Cotinine-induced convergence of the cholinergic and PI3 kinase-dependent anti-inflammatory pathways in innate immune cells. Biochim Biophys Acta 2008, 1783:375-382

20. Battersby S, Critchley HO, Morgan K, Millar RP, Jabbour HN: Expression and regulation of the prokineticins (endocrine gland-derived vascular endothelial growth factor and Bv8) and their receptors in the human endometrium across the menstrual cycle. J Clin Endocrinol Metab 2004, 89:2463-2469

21. Eskenazi B, Trupin LS: Passive and active maternal smoking during pregnancy, as measured by serum cotinine, and postnatal smoke exposure. II. Effects on neurodevelopment at age 5 years. Am J Epidemiol 1995, 142:S19-S29

22. Lee YL, Lee KF, Xu JS, Wang YL, Tsao SW, Yeung WS: Establishment and characterization of an immortalized human oviductal cell line. Mol Reprod Dev 2001, 59:400-409

23. Patrick DL, Cheadle A, Thompson DC, Diehr P, Koepsell T, Kinne S: The validity of self-reported smoking: a review and meta-analysis. Am J Public Health 1994, 84:1086-1093

24. Stillman RJ, Rosenberg MJ, Sachs BP: Smoking and reproduction Fertil Steril 1986, 46:545-566

25. Simon C, Valbuena D: Embryonic implantation. Ann Endocrino (Paris) 1999, 60:134-136

26. LeCouter J, Lin R, Tejada M, Frantz G, Peale F, Hillan KJ, Ferrara N The endocrine-gland-derived VEGF homologue Bv8 promotes angiogenesis in the testis: localization of Bv8 receptors to endothelial cells. Proc Natl Acad Sci USA 2003, 100:2685-2690

27. Smith SK: Angiogenesis and reproduction. BJOG 2001, 108:777-783

28. Hoffmann P, Feige JJ, Alfaidy N: Placental expression of EG-VEGF and its receptors PKR1 (prokineticin receptor-1) and PKR2 throughout mouse gestation. Placenta 2007, 28:1049-1058 